DOI: 10.19195/0524-4544.327.7

\author{
JÓZEF KOREDCZUK \\ ORCID: 0000-0002-3471-586X \\ Uniwersytet Wrocławski \\ jozef.koredczuk@uwr.edu.pl
}

\title{
Ochrona urzędników w kodyfikacji karnej obowiązującej na ziemiach byłego zaboru rosyjskiego w Polsce w latach 1918-1932
}

\begin{abstract}
Abstrakt: Ochrona urzędników ma na celu potrzebę zapewnienia funkcjonowania państwa będącego dobrem wspólnym wszystkich obywateli. Szczególnym rodzajem tej ochrony jest ochrona prawnokarna. Na ziemiach byłego zaboru rosyjskiego po 1918 roku, do czasu uchwalenia polskiego kodeksu karnego w 1932 roku, była ona udzielana na podstawie przepisów zawartych w części VI rosyjskiego kodeksu karnego z 1903 roku (tzw. kodeksu Tagancewa). Nie było to łatwe, gdyż charakteryzowała je zbytnia szczegółowość rozwiązań, co stwarzało problemy z ich stosowaniem w praktyce. Stosowanie tego kodeksu wymagało dostosowania jego starej treści do nowych warunków. Zapewnienie ochrony urzędnikom było jednakże jednym z głównych zadań odradzającego się państwa polskiego.
\end{abstract}

Słowa kluczowe: były zabór rosyjski, kodeks Tagancewa, nieposłuszeństwo wobec władzy, prawność żądania, urzędnik.

\section{Wstęp}

Z uwagi na potrzebę zapewnienia funkcjonowania państwa, będącego dobrem wspólnym wszystkich obywateli, każdy ustawodawca na ogół przewiduje wzmożoną ochronę osób wypełniających w jego imieniu określone funkcje. Osoby wypełniające wspomniane funkcje najczęściej określa się mianem urzędników, funkcjonariuszy państwowych. Ochrona urzędników wyraża się w ochronie przed bezpośrednimi działaniami ze strony innych osób starających się w różny sposób wpłynąć na wypełniane przez nie funkcje, względem tych osób przepisy prawa zaostrzają odpowiedzialność z uwagi na fakt, iż popełnione przez nie czyny pro- 
wadzą do zakłócenia wykonania zadań publicznych, a także godzą w powagę reprezentowanego przez funkcjonariusza publicznego urzędu ${ }^{1}$.

Z rozwiązaniem tego problemu musiało sobie poradzić odradzające się, młode państwo polskie po odzyskaniu w 1918 roku niepodległości, jeżeli chciało cieszyć się autorytetem na arenie międzynarodowej. Problem był o tyle skomplikowany, że nastąpiło to po 123 latach zaborów, a wzorce któregokolwiek z byłych państw zaborczych do tego się nie nadawały. Pierwszymi osobami, które w praktyce z tym problemem się mierzyły, byli urzędnicy. Oprócz walorów osobistych, jakie stawiano kandydatom na poszczególne urzędy, na straży ich autorytetu miały także stać przepisy prawa karnego, które są jednymi z tych, które z reguły w praktyce zapewniają największą ochronę prawną. Ochrona ta była częścią stosunku służbowego, jaki łączył urzędnika z państwem.

Relacje służbowe urzędnika w stosunku do państwa (,stosunek urzędniczy") z jednej strony wyrażały się w niemal bezwzględnym podporządkowaniu urzędnika państwu; z drugiej zaś strony, w jego prawie do specjalnej ochrony ze strony państwa w związku z piastowanym urzędem ${ }^{2}$. Ta specjalna ochrona obejmowała także ochronę prawnokarną. Szczególny charakter przybrała ona także w prawie obowiązującym na ziemiach w byłym zaborze rosyjskim, gdzie po odzyskaniu przez Polskę w 1918 roku niepodległości obowiązywał kodeks karny z 22 marca 1903 roku (tzw. kodeks Tagancewa). Uregulowanie przestępstw skierowanych przeciwko urzędnikom w tym kodeksie wynikało z rosyjskiej kultury prawnej i organizacji administracji oraz stosunku do niej zatrudnionych urzędników w okresie poprzedzającym jego uchwalenie. Po 1918 roku regulacjom tym przyszło obowiązywać w zupełnie nowych warunkach społeczno-politycznych, co miało istotny wpływ na status prawny urzędników odradzającego się państwa polskiego. Szczególne znaczenie kodeksu karnego Tagancewa w porównaniu do dwóch pozostałych kodyfikacji karnych (austriackiej z 1852 roku i niemieckiej z 1871 roku) wyrażało się w tym, że ziemie byłego zaboru rosyjskiego stanowiły 69\% terytorium II RP, która powstała po I wojnie światowej.

Pośrednio do kodeksu rosyjskiego odsyłał art. 26 wydanego jeszcze przed odzyskaniem przez Polskę niepodległości reskryptu Rady Regencyjnej z dnia 11 czerwca 1918 roku określającego tymczasowe przepisy służbowe dla urzędników państwowych i tabelę płac urzędników państwowych (Dz.Pr.Kr.Pol. Nr 6, poz. 13). Zgodnie z nim urzędnikom przysługiwało prawo szczególnej ochrony określone w ustawach sądowych i w kodeksie kar. Do tego przepisu nawiązano także w wydanej po odzyskaniu przez Polskę niepodległości Ustawie z dnia 17 lutego 1922 roku o państwowej służbie cywilnej (Dz.U. RP Nr 21, poz. 164),

${ }^{1}$ U. Gęślicka, Prawne i kryminologiczne aspekty wykonywania zawodu komornika sądowego, praca doktorska przygotowana pod kierunkiem prof. Edwarda Pływaczewskiego, Białystok 2016, s. 76.

2 A. Łukaszczuk, Kształtowanie się modelu ustrojowego stużby cywilnej w Polsce, Warszawa 2014, s. 20-21. 
która w art. 34 stanowiła, że urzędnikowi służy przy pełnieniu służby prawo do szczególnej ochrony prawnej określone w ustawach karnych. Podówczas tą ustawą karną był przede wszystkim kodeks rosyjski ${ }^{3}$.

W tym celu tuż przed ukonstytuowaniem się Sejmu Ustawodawczego, którego głównym zadaniem było opracowanie konstytucji przyszłego państwa polskiego, dnia 8 lutego 1919 roku ukazał się dekret Naczelnika Państwa zobowiązujący ministra sprawiedliwości do wydania autentycznego polskiego tekstu kodeksu karnego z 1903 roku, przy czym minister uzyskał prawo do przeprowadzenia w nim odpowiednich redakcyjnych zmian ${ }^{4}$. Wywiązując się z nałożonego obowiązku, w 1922 roku ministerstwo sprawiedliwości wydało Kodeks karny z r. 1903 (przektad z rosyjskiego). Z uwzględnieniem zmian i uzupetnień obowiazujacych w Rzeczypospolitej Polskiej w dniu 1 maja 1921 r., stanowiący oficjalne tłumaczenie na język polski kodeksu Tagancewa ${ }^{5}$.

$\mathrm{W}$ rosyjskim kodeksie Tagancewa przestępstwa, w ramach których urzędnik mógł stać się przedmiotem przestępstwa, zostały ujęte w części VI zatytułowanej $O$ niepostuszeństwie władzy. Przepisy zawarte w tej części charakteryzowały się większą punitywnością niż te następujące po nich. Wynikało to z faktu, że przestępstwo nieposłuszeństwa władzy godziło w państwo, stąd wzmożona represja. Postanowienia tych przepisów są charakterystyczne dla Rosji przełomu XIX i XX wieku — epoki dotykanej licznymi niepokojami społecznymi ${ }^{6}$.

\section{Nieposłuszeństwo władzy}

Ogólną formułę nieposłuszeństwa wobec władzy zawierał art. 139 kodeksu, zgodnie z nim karze podlegał każdy, kto wykroczył przeciw zarządzeniom prawnym lub sprzeciwił się żądaniu prawnemu urzędnika lub władzy. Kluczowym zagadnieniem statuującym urzędnika w szczególnej pozycji wobec osób niepo-

3 Warto dodać, że kwestie dotyczące ochrony prawnej urzędników w okresie międzywojennym nie były dotychczas przedmiotem większego zainteresowania prawników administratywistów, których głównie interesowały kwestie odpowiedzialności dyscyplinarnej urzędników i kwalifikacji kandydatów na określone urzędy. Historyków prawa zaś głównie interesowały przepisy kodeksu karnego z 1932 r., a prawie w ogóle dzieje kodyfikacji karnych pozaborowych po $1918 \mathrm{r}$.

4 A. Lityński, Dwa kodeksy karne 1932. W osiemdziesiąta rocznice, ,Roczniki Administracji i Prawa" 2012, t. 12, s. 211-212.

5 Był on także pięciokrotnie wydany przez Aleksandra Mogilnickiego i Emila Stanisława Rappaporta jako Ustawy karne tymczasowo obowiazujace w okręgach sąów apelacyjnych w Warszawie, Lublinie $i$ Wilnie w w latach 1922-1928; J. Koredczuk, Zwalczanie działalności ugrupowań komunistycznych w polskim prawie karnym okresu międzywojennego, „Acta Universitatis Wratislaviensis. Prawo" 2012, nr 3465, t. 314. Studia Historycznoprawne, s. 122, przyp. 9.

6 J. Sobczak, Nowy ,Kodeks karny” Cesarstwa Rosyjskiego z kwietnia 1903 r., [w:] Państwowość konstytucyjna XIX i XX wieku, red. E. Hull, E. Sokalska, Olsztyn 2015, s. 22. 
słusznych jego władzy była prawność jego żądania (działania). Była ona głównym przedmiotem wszystkich rozstrzygnięć sądowych dotyczących art. 139 kodeksu. Prawność żądania urzędnika w tym przypadku wynikała $\mathrm{z}$ uprawnień, jakie otrzymał on z upoważnienia władzy, oraz jego własnych pełnomocnictw z mocy piastowanego urzędu publicznego ${ }^{7}$. Uprawnienia te mogły mieć nawet charakter czasowy, jak to stwierdził w orzeczeniu z dnia 12 czerwca 1923 roku Sąd Najwyższy (akta nr 1447, 1923 r.) w odniesieniu do geometry, któremu władze państwowe zleciły wykonanie pomiarów, na dodatek na gruncie prywatnym, i który, dokonując tych pomiarów, działał w charakterze urzędnika ${ }^{8}$. Prawność żądania urzędnika w tych przypadkach wyrażała się w tym, że był on uprawniony do stawiania ogółowi ludności lub poszczególnym jej grupom określonych i stanowczych wymagań spełnienia tych czy innych zarządzeń bądź unikania pewnych czynności9

„Prawność” żądania, tj. jego zgodność z ustawą lub wydanym na mocy ustawy i należycie ogłoszonym rozporządzeniem właściwej władzy, była jedyną cechą, która „żądaniu” urzędnika lub władzy nadawała charakter obowiązujący i wymagający dla niej posłuchu pod groźbą kary z art. 139 kodeksu. Nikt nie mógł się uchylić od obowiązku wykonania żądania prawnego urzędnika, chociażby mogło się ono w danych warunkach wydawać niecelowe lub zgoła bezpodstawne. Osoba - do której urzędnik skierował żądanie leżące w dziedzinie i w zakresie jego służbowych uprawnień, a więc formalnie prawne - powinna była wykonać to żądanie, nawet gdyby miała wątpliwości co do jego merytorycznej słuszności, a to dlatego że każde żądanie urzędnika ma za sobą domniemanie słuszności zarówno ze względu na powagę władzy, jak i na prawność jej działania. Jeżeli z powodu wątpliwości czy żądanie urzędnika jest prawne osoba, do której je zwrócono, sprzeciwiła się prawnemu formalnemu żądaniu urzędnika, to wówczas sama ponosiła ryzyko ewentualnej odpowiedzialności za to sprzeciwienie się w wypadku, gdyby okazało się, że żądanie to było słuszne ${ }^{10}$.

Nieposłuszeństwo wobec władzy przewidziane w art. 139 kodeksu było wykroczeniem karanym grzywną lub aresztem, ale mogło także przybrać formę kwalifikowaną. Przy stosowaniu tegoż artykułu za urzędników kodeks nakazywał także uważać: a) kierowników pociągu ${ }^{11}$; b) kapitanów parowca lub innego statku

7 Uzasadnienie orzeczenia Sądu Najwyższego z dnia 7 stycznia 1919 r. (akta nr 112, 1918 r.); Zbiór Orzeczeń Sądu Najwyższego. Orzeczenia Izby (Karnej), Rok 1919, Warszawa [b.d.], poz. 1.

${ }^{8}$ Uzasadnienie Orzeczenia Sądu Najwyższego z dnia 12 czerwca 1923 r. (akta nr 1447, 1923 r.); Zbiór Orzeczeń Sądu Najwyższego. Orzeczenia Izby (Karnej), Rok 1923, Warszawa [b.d.], poz. 154.

9 Uzasadnienie Orzeczenia Sądu Najwyższego z dnia 10 stycznia 1919 r. (akta nr 35, 1918 r.); Zbiór Orzeczeń Sądu Najwyższego. Orzeczenia Izby (Karnej), Rok 1919, Warszawa [b.d.], poz. 3.

10 Ustawy karne tymczasowo obowiazujace w okręgach sadów apelacyjnych w Warszawie, Lublinie $i$ Wilnie, t. 1. Kodeks karny z ustawami dodatkowemi wydanemi do dnia 1 września 1927, tezami z orzeczeń Sąu Najwyższego i skorowidzem, red. A. Mogilnicki, E.S. Rappaport, Warszawa 1928, s. $160-161$.

11 Co ciekawe w trakcie prac nad ustawą z 1922 r. o państwowej służbie cywilnej, a także później do końca okresu międzywojennego odrzucano projekty zaliczenia do służby cywilnej tak- 
oraz c) wszystkie osoby, którym powierzono służbową opiekę nad bezpieczeństwem komunikacji lądowej lub wodnej. Rozciągnięcie ochrony przewidzianej w tym przepisie na inne osoby niebędące „,klasycznymi” urzędnikami świadczyło o tym, że intencją ustawodawcy było danie im wzmożonej ochrony ze względu na sprawowane przez nie funkcje publiczne ${ }^{12}$.

Na marginesie należy dodać, że niedoskonałością przepisów - i to nie tylko kodeksu karnego rosyjskiego - było to, że nie określały one pojęcia urzędnika. Już dawniej niektórzy autorzy dzieł prawniczych zwracali uwagę na to, że pojęcie urzędnika w znaczeniu przyjętym przez prawo karne nie odpowiada pojęciu urzędnika w znaczeniu ogólnie znanym i rozumianym i że jest bardzo elastyczne, a sądy miały trudne zadanie przy ustalaniu w poszczególnych przypadkach, czy daną osobę traktować należy jako urzędnika. Praktyka sądowa przyjęła, że za urzędnika trzeba uważać osobę, która w imieniu władzy publicznej, państwowej lub samorządowej spełnia czynności w myśl obowiązujących dla tej władzy przepisów, bez względu na to czy i jakie sama zajmuje stanowisko ${ }^{13}$.

Kwalifikacja nieposłuszeństwa wobec władzy zgodnie z art. 142 kodeksu mogła ulec zmianie, jeżeli osoba, która się go dopuściła, stawiała opór urzędnikowi lub pomagającej jemu osobie za pomocą gwałtu na osobie lub karygodnej groźby, groziła jej bowiem wtedy kara zamknięcia w więzieniu. Jeżeli taki opór stawiło kilka osób, nie tworzących jednak cech zbiegowiska przestępnego, to tylko ten z winowajców, który przy tym oporze użył broni lub zrządził uszkodzenie ciała, miał być karany zamknięciem w domu poprawy. Artykuł powyższy miał także odpowiednie zastosowanie w stosunku do osób odpowiedzialnych za bezpieczeństwo w komunikacji kolejowej lub wodnej.

Czynna napaść, z którą mieliśmy w tym przypadku do czynienia, była najgroźniejszym i zarazem najbardziej niebezpiecznym z przestępstw skierowanych „Z zewnątrz” przeciwko działalności urzędników ${ }^{14}$.

Niekiedy czynna napaść na urzędnika mogła łączyć się także z jego znieważeniem. Sytuację taką przewidywał art. 154 ust. 4 kodeksu stanowiący o nieposzanowaniu władzy okazanym przez popełnienie gwałtu na osobie kogokolwiek z członków instytucji rządowej lub społecznej w czasie zajęć służbowych w tej instytucji. Sprawca tego przestępstwa podlegał wówczas karze zamknięcia w domu poprawy. By pociągnąć sprawcę tego przestępstwa do odpowiedzialności, sąd musiał ustalić, co nie zawsze było proste, czy celem jego działania była tylko napaść

że pracowników kolejnictwa oraz wszystkich organizacji związanych z koleją. Por. A. Łukaszczuk, Ksztaltowanie się modelu..., s. 26.

12 T. Rzepecki, A. Bałko, Zakres karnoprawnej ochrony konduktora PKP, „Nowe Prawo” 1967, R. 23, nr 11, s. 1475.

13 W. Osuchowski, Odpowiedzialność karna pracowników państwowych, samorząd. i spótdzielczych, Warszawa 1948, s. 15-16.

14 E. Pływaczewski, Przestęstwo czynnej napaści na funkcjonariusza publicznego, Toruń 1985, s. 5. 
na urzędnika, czy także chęć jego znieważenia ${ }^{15}$. Jednakże z punktu widzenia ochrony urzędnika kumulacja tych dwóch form agresywnego zachowania sprawcy świadczyła o dążeniu ustawodawcy do zapewnienia urzędnikom ochrony szerszej niż tylko w oparciu o jedno kryterium.

Rozciągnięcie ochrony przewidzianej w art. 139 i 142 kodeksu na inne oprócz urzędników osoby wymusiło życie i praktyka sądowa, które uznały, że osoby te, mimo że nie zajmowały właściwych stanowisk urzędniczych, były jednakże pracownikami państwowymi bądź też funkcjonariuszami instytucji mających duże znaczenie dla życia państwa ${ }^{16}$. Osoby zajmujące wspomniane stanowiska tradycyjnie zaliczano do „stanowisk powołanych do ochrony porządku i bezpieczeństwa publicznego" $" 17$.

Identyczną kwalifikację prawną jak w art. 142 kodeksu miało również nieposłuszeństwo wobec władzy przewidziane w art. 145 kodeksu, które polegało na zmuszeniu urzędnika do niespełnienia przezeń swego obowiązku lub do nadużycia pełnomocnictw służbowych. Różniło się natomiast tym, że było karalne nie tylko jego dokonanie, ale również usiłowanie.

\section{Prawnokarna ochrona urzędników}

Karalność usiłowania zmuszenia urzędnika do niespełnienia swego obowiązku lub nadużycia pełnomocnictw służbowych zależna była od tego, czy był on zmuszany do popełnienia występku czy zbrodni. Jeśli sprawca zmuszał urzędnika do popełnienia występku, wówczas podlegał zamknięciu w domu poprawy na czas do lat trzech; jeśli natomiast zmuszał go do popełnienia zbrodni, to wówczas podlegał zamknięciu w domu poprawy na czas nie krótszy od lat trzech. Jeśli występek, zbrodnia lub karygodne ich usiłowanie zostały przez zmuszonego urzędnika popełnione, a zmuszający nie podlegał za nie surowszej karze, wówczas jako wspólnik popełnionego przestępstwa miał być on ukarany: za zmuszenie do występku — zamknięciem w domu poprawy, a za zmuszenie do zbrodni — ciężkimi robotami na czas do lat ośmiu (art. 146).

Kwalifikowaną odmianę zmuszenia urzędnika przewidzianą w art. 145 kodeksu stanowiło również doprowadzenie go do stanu nieprzytomności wbrew jego woli w celu pozbawienia go możności spełnienia swego obowiązku. Zarówno sprawca tego czynu, jak i osoba która usiłowała do tego doprowadzić, zgodnie $\mathrm{z}$ art. 147 kodeksu podlegali karze więzienia. Co ciekawe, dopuszczano w praktyce

15 O. Górniok, Granice pojęcia „,czynna napaść” w kodeksie karnym, „Nowe Prawo” 1970, R. 27, nr 7-8, s. 1059.

16 W. Osuchowski, op. cit., s. 12-13.

17 E. Pływaczewski, Przestępstwo czynnej..., s. 20. 
możliwość doprowadzenia urzędnika do tego stanu za pomocą wszelkich środków, w tym za pomocą zwykłego upojenia alkoholowego ${ }^{18}$.

Przepisy dotyczące ochrony urzędników, jak już wspominałem, miały także zastosowanie w stosunku do osób odpowiedzialnych za zapewnienie bezpieczeństwa w komunikacji kolejowej lub wodnej. Jakiekolwiek zmuszenie tych osób, tj. kierującego pociągiem lub kapitana parowca albo statku morskiego, do niespełnienia nałożonych na nich obowiązków lub doprowadzenie ich w tym celu do nieprzytomności było karane więzieniem. Jeżeli w następstwie tych działań wynikło niebezpieczeństwo rozbicia pociągu, parowca lub statku morskiego, to wówczas zgodnie z art. 148 kodeksu winowajcy groziła kara zamknięcia w domu poprawy, a jeżeli doszło do ich rozbicia, to kara ciężkich robót orzeczona na określony czas. Dalsze zaostrzenie wymienionych kar następowało, jeżeli sprawca, który zmusił wspomniane osoby do zaniechania przez nie określonych obowiązków, uczynił to świadomie w celu rozbicia wymienionych środków komunikacji.

Prawnokarnej ochronie podlegały także kompetencje przysługujące danemu urzędnikowi przed przywłaszczeniem ich sobie przez inne nieuprawnione osoby. Jeżeli osoba do tego nieuprawniona samowolnie przybrała sobie godność urzędnika celem spełnienia czynności lub spełniła czynność, która mogła być dokonana tylko przez urzędnika, wówczas podlegała karze aresztu lub grzywny. Dalej cytowany art. 151 kodeksu stanowił, że jeżeli winny przywłaszczenia władzy popełnił za pomocą nadużycia przywłaszczonej sobie władzy występek lub zbrodnię, to miał być karany według przepisów o zbiegu przestępstw. I jeżeli winny przywłaszczenia sobie władzy popełnił czyn odpowiadający zbrodni lub występkowi w służbie państwowej lub społecznej, podlegał tej samej karze, której za taki czyn uległby urzędnik. Artykuł 151 kodeksu dopuszczał rzadko spotykany na gruncie prawa karnego idealny zbieg przestępstw. Ustawodawca zgodził się na niego w tym przypadku, ponieważ zależało mu na pewnego rodzaju wzmocnieniu represji w przypadku, gdy uzurpujący władzę przy pomocy takiego nadużycia popełnił cięższe przestępstwo (występek lub zbrodnię) ${ }^{19}$. Warto przy tym zwrócić uwagę, że przepis art. 151 kodeksu chronił tylko urzędników państwowych lub samorządowych, z wykluczeniem innych osób lub instytucji ${ }^{20}$.

Przed groźbą przywłaszczenia sobie kompetencji kodeks oprócz właściwych urzędników chronił także inne osoby sprawujące funkcje publiczne. Dotyczyło to rabinów i ich pomocników, w przypadku których, gdy ktoś samowolnie spełniał

18 Kodeks karny obowiąujacy tymczasowo w Rzeczypospolitej Polskiej na ziemiach b. zaboru rosyjskiego z dodaniem: przepisów przechodnich i ustaw, zmieniających i uzupetniajacych postanowienia karne kodeksu, odpowiednich przepisów Kodeksu Karnego Niemieckiego i Ustawy Karnej Austriackiej, obowiazujacych w pozostałych dzielnicach Rzplitej oraz Komentarza i orzeczeń Sąu Najwyższego, t. II. Cz. 2-19 k.k., red. W. Makowski, Warszawa 1921, s. 164.

19 S. Śliwiński, Czy Kodeksowi Karnemu z roku 1903 znany jest idealny zbieg przestępstw?, „Kwartalnik Prawa Cywilnego i Karnego” 1919, R. 2, s. 134-137.

20 Ustawy karne..., s. 181. 
nałożone na nich przez ustawę obowiązki, zgodnie z art. 152 kodeksu podlegał karze zamknięcia w więzieniu. Również osoba, która - będąc wezwana do sprawowania funkcji członka ławy przysięgłych - wobec sądu podała się za inną osobę, podlegała karze grzywny, a jeżeli rzeczywiście wypełniła ten obowiązek, to wówczas podlegała karze aresztu (art. 153 kodeksu). Przy tym delikcie karze podlegał także podżegacz do tego przestępstwa, jeżeli nastąpiło jego dokonanie. Artykuł 153 kodeksu pozostał „martwą literą” na skutek niewprowadzenia na ziemiach byłego zaboru rosyjskiego po 1918 roku sądów przysięgłych.

Przepisy regulujące funkcjonowanie różnych urzędów określają także na ogół zasady zachowania się w nich osób załatwiających konkretne sprawy lub przebywających, a niebędących urzędnikami. Przepisy te mają również na celu zachowanie powagi urzędu i osób w nim zatrudnionych. Według art. 154 kodeksu, nieposzanowanie władzy mogło się wyrazić w postępowaniu danej osoby wyraźnie nieprzystającym (nieprzystojnym) instytucji rządowej lub społecznej w czasie zajęć służbowych w tej instytucji. Osoba, która dopuściła się takiego zachowania, podlegała karze aresztu.

Kwalifikowaną formą nieprzystojnego zachowania było znieważenie wspomnianych instytucji, które mogło nastąpić za pomocą pisma złożonego do takiej instytucji albo w wygłoszonych lub odczytanych publicznie mowie albo utworze, w druku, piśmie lub wizerunku rozpowszechnionych lub publicznie wystawionych. Mogło to nastąpić nawet w pismach składanych przez strony w ramach toczącego się przeciwko nim postępowania sądowego skierowanych do konkretnej osoby (urzędnika). Przy czym, jak zauważył w orzeczeniu z dnia 27 lipca 1923 roku Sąd Najwyższy (akta nr 3302, 1923 r.), nie każde znieważenie urzędnika było równocześnie nieposzanowaniem władzy przez zniewagę samej instytucji w której on pracował, o które chodzi w art. 154 kodeksu ${ }^{21}$. Sprawca znieważenia instytucji podlegał karze zamknięcia w więzieniu. Zaostrzona kara zamknięcia w domu poprawy groziła także sprawcy znieważenia instytucji lub kogokolwiek z jej członków, jeżeli nastąpiła w trakcie zajęć służbowych w tej instytucji.

Artykuł 154 kodeksu nie miał na względzie poszczególnych urzędników państwowych i ochronę ich czci, to bowiem stanowiło przedmiot stanów faktycznych przestępstw przeciwko osobie przewidzianych w części XXVIII kodeksu, lecz miał na celu ochronę powagi i poszanowania władzy państwowej jako całości. Władzy, która była uosobieniem organizacji państwowej i prawidłowego jej funkcjonowania. Urzędami państwowymi według art. 154 kodeksu były nie tylko urzędy administracyjne, ale wszelkie instytucje, organy życia państwowego i społecznego, którym powierzono opiekę w zakresie jakiejkolwiek dziedziny życia organizacji państwowej22.

21 Uzasadnienie Orzeczenia Sądu Najwyższego z dnia 12 czerwca 1923 r. (akta nr 3302, 1923 r.); Zbiór Orzeczeń Sądu Najwyższego. Orzeczenia Izby (Karnej), Rok 1923, Warszawa [b.d.], poz. 167.

22 Kodeks karny..., s. 181. 


\section{Przestępstwa przeciwko urzędnikom samorządowym}

Kodeks Tagancewa — według współczesnej terminologii nieobecnej w nim samym - chronił także urzędników samorządowych. Zgodnie z art. 140 przewidywał on karę grzywny 50 rubli dla osoby postronnej, która nie podporządkowała się uprawnionemu żądaniu przewodniczącego zebrania stanowego lub społecznego. Jeżeli wskutek tego nieposłuszeństwa danej osoby nastąpiło przerwanie posiedzenia, wówczas sprawca ponosił zaostrzoną karę 100 rubli. Taką samą karę ponosił członek wspomnianego zebrania, jeżeli w jego trakcie podjął czynności mające na celu przedłużenie posiedzenia lub powzięcie uchwały po jego zamknięciu przez przewodniczącego bądź samowolnie otworzył posiedzenie rozwiązanego zebrania. Jeżeli w następstwie tego została powzięta uchwała, która wykraczała poza granice uprawnień przyznanych rzeczonemu zebraniu przez ustawę, wówczas zgodnie z art. 141 kodeksu sprawca tego nieposłuszeństwa podlegał karze grzywny, chyba że z powodu treści powziętych uchwał wynikałaby surowsza kara. W przypadku przywłaszczenia funkcji urzędnika stanowego lub społecznego kodeks przewidywał ponadto w stosunku do sprawcy tego deliktu karę dodatkową w postaci możliwości zakazania mu przez sąd uczestnictwa we wspomnianych zebraniach na czas od jednego do trzech okresów wyborczych.

Przepisy art. 140 i 141 kodeksu stanowiły kazuistyczne rozwinięcie postanowień art. 139. Były one przystosowane do organizacji samorządu stanowego w Rosji w okresie, gdy redagowano kodeks. Po 1918 roku straciły one swoją aktualność z wyjątkiem prawnokarnej ochrony mającej na celu zachowanie powagi zarządzeń przewodniczącego na posiedzeniach różnych instytucji społecznych, do których miały one odpowiednie zastosowanie, jeżeli przepisy dotyczące funkcjonowania tych instytucji takowych przepisów nie posiadały ${ }^{23}$.

Karalne było również przeszkadzanie osobie urzędowej w przedostaniu się do budynku, pomieszczenia lub innego miejsca, do których osoba taka wejść miała prawo według ustawy. Groziła za to sprawcy przestępstwa kara aresztu lub grzywny. Tej samej karze podlegał także winny umyślnego niedopuszczenia przedstawiciela dozoru handlowego do spełnienia nałożonych nań przez ustawę o państwowym podatku od procederów obowiązków w zakresie doglądania prawidłowego obciążenia tym podatkiem handlu i innych procederów (art. 143 kodeksu).

Ochronie prawnokarnej podlegały także atrybuty związane z piastowaniem przez daną osobę określonego urzędu. Zgodnie bowiem z art. 114 kodeksu, winny bądź uszkodzenia pieczęci lub innego znaku, nałożonych z rozporządzenia osoby urzędowej w przypadkach przez ustawę wskazanych na pomieszczeniu, schowaniu lub przedmiocie celem ich zabezpieczenia, bądź otwarcia dostępu do

23 Ibidem, s. 151. 
takiego opieczętowanego pomieszczenia lub schowania, podlegał karze zamknięcia w więzieniu. Uszkodzenie pieczęci bądź innego znaku albo otwarcie dostępu do opieczętowanego pomieszczenia lub schowania w tym przypadku nie miało być uważane za przestępstwo, jeżeli czynów tych dopuścił się gospodarz opieczętowanego pomieszczenia, schowania lub przedmiotu po zapadnięciu w trybie właściwym decyzji lub podlegającego wykonaniu rozporządzenia o zdjęciu pieczęci lub znaku albo po zaspokojeniu osoby, w której interesie dokonano opieczętowania. W przypadku powyższego deliktu karalne było również usiłowanie jego popełnienia.

Również wystawione publicznie z rozporządzenia odnośnej władzy obwieszczenia lub inne dokumenty rządowe lub społeczne, napisy, herby, a także inne znaki władzy oraz wojskowe chorągwie, sztandary i wojenne flagi morskie podlegały ochronie. Jeżeli dana osoba w sposób umyślny dopuściła się ich zdarcia, uszkodzenia lub skażenia, to wówczas zgodnie z art. 155 kodeksu podlegała karze aresztu lub grzywny, nie surowszej jednakże niż kara przewidziana za dokonane uszkodzenie dokumentu. Jeśli sprawca niniejszego wykroczenia popełnił je celem okazania nieposzanowania władzy, wówczas podlegał karze zamknięcia w więzieniu. Jeżeli natomiast to nieposzanowanie władzy polegało na zdarciu, uszkodzeniu lub skażeniu manifestu lub rozkazu najwyższej władzy państwowej wystawionego publicznie, wówczas winowajca miał być ukarany zamknięciem w domu poprawy.

\section{Zakończenie}

Stosowanie przez prawie czternaście lat po odzyskaniu przez Polskę niepodległości rosyjskiego kodeksu z 1903 roku wymagało dostosowania jego starej treści do nowych warunków, dotyczyło to zwłaszcza jego części szczególnej.

Uregulowania części VI kodeksu Tagancewa charakteryzowała bowiem zbytnia szczegółowość rozwiązań, co stwarzało problemy z jej stosowaniem w praktyce. Praktyka ta pokazuje, że działało to najczęściej na korzyść osób oskarżonych o nieposłuszeństwo wobec władzy, a przyczyniało się niekiedy do niezbyt pełnej ochrony urzędników, jaką potencjalnie dawały przepisy kodeksu z 1903 roku. Z tych też powodów część szczególną kodeksu z 1903 roku oceniano znacznie niżej niż część ogólną ${ }^{24}$. Autorytet państwa i reprezentujących go urzędników wymagał, by podjąć starania mające na celu opracowanie przepisów, które będą lepiej chronić niż kodeks z 1903 roku stosunki społeczne w powstającej II RP.

Próbując pogodzić wcześniejsze rozbieżności i ujednolicić przestępstwa wobec urzędników, w kodeksie karnym z 1932 roku nie określono żadnego poję-

24 K. Laskowska, Przestępczość w Rosji z perspektywy kryminologii i prawa karnego, Białystok 2016, s. 25-26. 
cia urzędnika. Wychodząc z założenia, że jakakolwiek definicja je przewidująca będzie zbyt ciasna. Nie będzie uwzględniała zmieniających się funkcji państwa realizowanych przez administrację, nie będzie obejmowała wszystkich zdarzeń, które mogą w praktyce wystąpić. Dlatego też zamiast definiować pojęcie urzędnika w kodeksie, usiłowano określać je, kierując się tendencjami w orzecznictwie. $\mathrm{Z}$ mnogości tych orzeczeń wysuwało się jedno wspólne kryterium wskazujące, kogo należy rozumieć jako urzędnika, osobę będącą przedmiotem szczególnej ochrony prawnokarnej. Były to osoby pozostające w służbie państwa lub samorządu, jak również osoby wojskowe, a inne osoby tylko jeżeli wykonywały czynności zlecone w zakresie zarządu państwowego lub samorządowego ${ }^{25}$.

Uprzywilejowanie zawodu urzędniczego wyrażało się również w specjalnej ochronie ze strony prawa karnego. W tym przypadku chodziło jednak o ochronę prawną każdej osoby wykonującej jakikolwiek urząd państwowy, a więc ochrona ta nie była wyłącznym przywilejem zawodowym biurokracji. Prawnokarna ochrona urzędników przewidziana w kodeksach karnych była jedną z gwarancji umożliwiających im realizację uprawnień związanych z pełnioną przez nich funk$\mathrm{cją}^{26}$. Państwo $\mathrm{z}$ tego tytułu zobowiązało swoje organy do ścigania przestępstw przeciwko urzędnikom z urzędu. Nie wykluczało to jednak także prawa samego zainteresowanego urzędnika do upominania się o tę ochronę. Prawo to miało bowiem charakter publicznoprawny ${ }^{27}$. Ochrona ta była o tyle istotna, że obejmowała także osoby piastujące urzędy, których nie objęła ustawa o państwowej służbie cywilnej z 1922 roku.

Pisząc o prawnokarnej ochronie urzędników, należy pamiętać, że prawo karne spełnia funkcję ochronną i gwarancyjną i że w postępowaniu przed urzędem zawsze są dwie strony (urzędnik i petent), w związku z czym powinna być między tymi funkcjami zachowana należyta równowaga ${ }^{28}$.

\section{Bibliografia}

Gęślicka U., Prawne i kryminologiczne aspekty wykonywania zawodu komornika sądowego, praca doktorska przygotowana pod kierunkiem prof. Edwarda Pływaczewskiego, Białystok 2016.

25 M. Siewierski, Urzędnik jako przedmiot przestępstwa, „Głos Sądownictwa” 1932, R. 4, nr 9, s. 542-543.

26 A. Łukaszczuk, Stużba cywilna w II Rzeczypospolitej, „Acta Universitatis Wratislaviensis. Przegląd Prawa i Administracji” 2010, nr 3264, t. 83, s. 236; A. Łukaszczuk, Kształtowanie się modelu..., s. 20-21.

27 W. Jaśkiewicz, Studia nad sytuacją prawna pracowników państwowych, t. 1. Formy prawne stużby państwowej w niemieckim prawie urzędniczym. Stosunek stużbowy w prawie urzędniczym $R P$, Poznań 1961, s. 70, 137.

28 E. Pływaczewski, Wokół zagadnienia ochrony karnoprawnej funkcjonariusza organu ochrony bezpieczeństwa i porządku publicznego, „Państwo i Prawo” 1983, R. 38, z. 1, s. 100. 